\title{
Level of Correlation in the Depth of Groundwater Wells: Iron and Chloride
}

\section{Ronny $^{1}$, Erlani' ${ }^{1}$, Jasman ${ }^{2}$}

1. Poltekkes Kemenkes Makassar, Department of Environmental Health, South Sulawesi, Indonesia

2. Poltekkes Kemenkes Manado, Department of Environmental Health, North Sulawesi, Indonesia

\begin{abstract}
:
Groundwater quality in each region is not always the same, this influenced by climate factors, lithology, time, human activities. The purpose of the research that conducted was to see the relationship among the depth of groundwater wells in two different study locations on the concentration of iron (Fe) and Chloride ( $\mathrm{Cl}$ ) levels in each sample. This research located in Mattiro Baji Village, Pangkep Regency, South Sulawesi and Sindulang Satu Urban Village, Manado City, North Sulawesi. The research sample amounted to 18 in the form of bottles of groundwater well samples which evenly taken at the study site. TDS Meter is used to quantity iron (Fe) concentration, and Chlorine Meter is chloride $(\mathrm{Cl})$ levels in samples with $\mathrm{mg} / \mathrm{L}$. The outcomes of the study showed that there was no noteworthy relationship between the depth of groundwater wells and the levels of concentration of iron (Fe) and Chloride (Cl). Conditions that are still not contaminated by changes caused by the environment, industrial waste and seawater intrusion.
\end{abstract}

Keywords: Dug Well, Contamination, Groundwater, Water Quality.

\section{References}

1. Cheng, A.H.D. 2000. Multilayered Aquifier Systems: Fundamentals and Applications. CRC Press.

2. Gelhar, L.W. 1993. Stochastic subsurface hydrology. Prentice-Hall.

3. Dunne, T. and L.B. 1978. Leopold Water in environmental planning. Macmillan.

4. $\quad$ Fried, J.J. 1975. Groundwater pollution. (vol. 4). Elsevier.

5. WHO/UNICEF Joint Water Supply and S.M.P. 2015. Progress on sanitation and drinking water: 2015 update and MDG assessment. World Health Organization, Geneva.

6. Ronny, G.D. Dirawan, M. Basir. 2016. Strategies of Sanitation Environmental Counselling Towards Increasing Attitude of Community on Preserve Environment in Makassar City. Int J Appl Environ Sci., 11(3):741-749.

7. Ronny, et al. 2015. Strategies for increasing Awareness on Environmental Sanitation in Maintenance Knowledge Society Environment in Makassar. Man in India., 96(5):795-803.

8. Foster, S., et al. 2002. Groundwater quality protection: a guide for water service companies, municipal authorities and environment agencies. The World Bank.

9. WHO. 2010. UN-Water Global Assessment of Sanitation and Drinking Water: Targeting resources for better results. World Health Organization. Geneva.

10. WHO. 2004. Guidelines for drinking-water quality: Recommendations. (vol. 1). World Health Organization. Geneva.

11. European Community. 1998. Council Directive 98/83/EC on the quality of water intended for human consumption. Official Journal of the European Communities.

12. U. S Food and Drug Administration. 2017. Food and Drugs. In: Revision. U.S Department of Health and Human Services.

13. Krist, H. and H.H Rump. 1988. Laboratory Manual for Examination of Waste and Soil. Winhelm, London. 
14. Sawyer, C.N. and P.L McCarty. 1978. Chemistry for environmental engineers. McGraw-Hill Book Company, New York.

15. Clarke, F.E., 1980. Corrosion and encrustation in water wells: a field guide for assessment, prediction and control. (vol. 34). Food \& Agriculture Organization.

16. Ronny and A.H. Hasim. 2018. Effectiveness of Multiple Tray-Aerators in Reducing Iron (Fe) Water Wells in Gowa Regency, Indonesia. Eco. Env. and Cons. 24(1):22-25.

17. McArthur, J.M. 1999. Reply: Arsenic poisoning in the Ganges delta. Nature. 401(6753):546.

18. Venkateshwarlu, M., A. Kiran Kumar and M. Narsi Reddy. 2018. Groundwater quality assessment in Kandlakoya village by chemical methods. Indian J. Env. Prot.

19. Van der Bruggen, B and C. Vandecasteele. 2003. Removal of pollutants from surface water and groundwater by nanofiltration: overview of possible applications in the drinking water industry. Env. Poll., 122(3):435-445.

20. Bouwer, H. 2002 b. Integrated water management for the 21st century: problems and solutions. J Irrigation Drainage Eng., 128(4):193-202.

21. Setiono, I.M, et al. 2012. Indonesia - Water investment Roadmap: 2011-2014. Water Partnership Program (WPP). World Bank Group, Washington, D.C.

22. Krishnamoorthy, S., A. Murugesan and R. Babu. 2018. Trends on groundwater quality in cuddalore district. Vol. 38, Indian J. Env. Prot.

23. Winter, T.C. 1998. Groundwater and surface water: a single resource. (vol. 1139). Diane Publishing Inc.

24. Montgomery, M.A, and M. Elimelech. 2007. Water and sanitation in developing countries: including health in the equation. ACS Publications.

25. Creswell J.W., 2014. Research Design: Qualitative, Quantitative, and Mixed Method Approaches. (4th edn.) SAGE Publications, Inc., Thousand Oaks, California.

26. Keith, L.H. 1988 Principles of environmental sampling.

27. Moe, C.L. and R.D. Rheingans. 2006. Global challenges in water, sanitation and health. J Water Health., 4(S1):41-57.

28. Ifabiyi, I.P. 2008. Depth of Hand Dug Wells and Water Chemistry: Example from Ibadan Northeast Local Government Area (LGA), Oyo-State, Nigeria. J Social Sci., 17(3):261-6.

29. Alam, M.G.M, et al. 2002. Arsenic contamination in Bangladesh groundwater: a major environmental and social disaster. Int. J. Env. Health Res., 12(3):235-253.

30. Schwarzenbach, R.P. et al. 2006. The challenge of micropollutants in aquatic systems. Sci., 313(5790):1072-1077.

31. Berg, M., et al. 2001. Arsenic contamination of groundwater and drinking water in Vietnam: a human health threat. Env. Sci. and Tech., 35(13):2621-2626.

32. Lilja, A and G. Linde. 2006. Occurrence and distribution of heavy metals in three rivers on the Bolivian high plateau.

33. Smith A.H., E.O. Lingas and M. Rahman. 2000. Contamination of drinking-water by arsenic in Bangladesh: a public health emergency. Bulletin World Health Organization. 78:1093-1103.

34. Jickells, T.D., et al. 2005. Global iron connections between desert dust, ocean biogeochemistry and climate. Sci., 308(5718):67-71.

35. Kar, D., et al. 2008. Assessment of heavy metal pollution in surface water. Int. J. Env. Sci. Tech., 5(1):119-124. https://doi/10.1007/BF03326004.

36. Nouri, J., et al. 2008. Regional distribution pattern of groundwater heavy metals resulting from agricultural activities. Env. Geology., 55(6):1337-1343. https://doi/10.1007/soo254-0071081-3.

37. Hillel, D. 2012. Soil and water: physical principles and processes. Elsevier.

38. Lavelle, P and S.V. Spain. 2001. Soil ecology. Springer Science \& Business Media.

39. Tisdall, J.M. and J. Oades. 1982. Organic matter and water-stable aggregates in soils. J. Soil Sci., 33(2):141-163.

40. de Vries J.J. 2016. History of groundwater hydrology. In: The Handbook of Groundwater Engineering, (3rd edn). CRC Press. pp 21-48. 
41. Kaur, R., et al. 2018. Assessment of water quality, heavy metal contamination and its indexing approach of Dhanas Lake in Patiala Ki Rao reserved forest area, Chandigarh. Indian J. Env. Prot.

42. Bouwer H. 2002. Artificial recharge of groundwater: hydrogeology and engineering. Hydrogeol J., 10(1):121-42.

43. Bronick C.J. and R. Lal. 2005. Soil structure and management: a review. Geoderma., 124(1-2):322.

44. Bear J. 2012. Hydraulics of groundwater. Courier Corporation.

45. Goel, P.K. 2006. Water pollution: causes, effects and control. New Age International.

46. Novotny, V. 2003. Water quality: diffuse pollution and watershed management. John Wiley \& Sons.

47. Oller, A. and H. Bates. 2004. Metals in Perspective Groundwater arsenic contamination and its health effects in the Ganga-Meghna-Brahmaputra plain. J. Env. Monitoring., 6(6):74N-83N. 